\title{
Polymorphisms of GSTM1, GSTT1, GSTP1 and CYP1A1 genes and susceptibility to lung cancer
}

\author{
Paula Mota ${ }^{1 *}$, Michelle Horta ${ }^{2}$, Luis Mesquita ${ }^{1,3}$, Henriqueta Silva ${ }^{1,3}$ \\ From 16th International Charles Heidelberger Symposium on Cancer Research \\ Coimbra, Portugal. 26-28 September 2010
}

Biotransformation enzymes are related with lung cancer that arises as a consequence of exposure to mutagenic agents. CYP1A1 gene codifies the phase I enzyme, aryl hydrocarbon hydroxilase, belonging to the Cytochrome P450 system, that plays a major role in the bioactivation of tobacco procarcinogenes, while glutathione-Stransferases genes, GSTM1, GSTT1 and GSTP1, codify conjugation enzymes associated with detoxification processes of free radicals, xenobiotics and cytotoxic drugs [1]. Our main goal was to verify possible associations between polymorphisms of these genes and susceptibility to lung cancer.

CYP1A1 polymorphisms, $\mathrm{m} 1$ (T6235C) and $\mathrm{m} 2$ (A4889G) were studied by RFLP assay, GSTM1 and GSTT1 (GSTM1*0 and GSTT1*0) by PCR multiplex and GSTP1 (rs1695) by real time PCR, in 197 patients and 237 controls. For CYP1A1 alleles and genotype distributions, no statistically significant differences were found between both populations. GSTT1 "0/" 0 genotype was associated with a higher susceptibility to lung cancer (OR: 1.6; 95\%CI: 1.02-2.44; $\mathrm{p}<0.05$ ). In the patient population, smoking burden of 21-100 pack-years were more frequently associated with GSTT1 ${ }^{*} 0 / * 0$ genotype than in controls $(\mathrm{p}<0.02)$. This difference was even more significant for ex-smokers $(\mathrm{p}<0.001)$. Gene copy number assay exposed an association between GSTM1*1/*0 and lung cancer $(\mathrm{p}<0.001)$.

The results reveal a possible association between GSTT1 ${ }^{*} 0 / * 0$ and susceptibility to lung cancer related with smoking habbits.

\footnotetext{
* Correspondence: motapaula8@gmail.com

'Unidade de Genética Médica, Faculdade de Medicina, Universidade de Coimbra, Coimbra, Portugal

Full list of author information is available at the end of the article
}

\section{Author details}

'Unidade de Genética Médica, Faculdade de Medicina, Universidade de Coimbra, Coimbra, Portugal. 'Departamento de Ciências da Vida, Faculdade de Ciências e Tecnologia, Universidade de Coimbra, Coimbra, Portugal. ${ }^{3}$ Centro de Pneumologia, Faculdade de Medicina, Universidade de Coimbra, Coimbra, Portugal.

Published: 24 September 2010

\section{Reference}

1. Taioli E: Gene-environment interaction in tobacco-related cancer. Carcinogenesis 2008, 29:1467-1474.

doi:10.1093/carcin/bgn062

Cite this article as: Mota et al:: Polymorphisms of GSTM1, GSTT1, GSTP1 and CYP1A1 genes and susceptibility to lung cancer. BMC Proceedings 2010 4(Suppl 2):P4.
Submit your next manuscript to BioMed Central and take full advantage of:

- Convenient online submission

- Thorough peer review

- No space constraints or color figure charges

- Immediate publication on acceptance

- Inclusion in PubMed, CAS, Scopus and Google Scholar

- Research which is freely available for redistribution

Submit your manuscript at www biomedcentral com/submit
Biomed Central 